\title{
Language as an Object of Empirical Study in the Dutch Republic
}

\author{
ELS STRONKS
}

Els Stronks is Professor of Early Modern Dutch Literature and Culture at Utrecht University. She previously taught at Indiana University, Bloomington. She has widely published on visual culture as reflected in Dutch literature, including Negotiating Differences. Word, Image and Religion in the Dutch Republic (2011), and the Emblem Project Utrecht (EPU). Her other professional interests include the knowledge culture of the Dutch Republic and technical approaches used in the field of early modern studies. The authorship of the Dutch anthem serves as a case study. Together with Mike Kestemont, Martine de Bruin, and Tim de Winkel she has recently published Van wie is het Wilhelmus? De auteur van het Nederlandse volkslied met de computer onderzocht.

\begin{abstract}
This article takes a dictionary by Joos Lambrecht, dating from 1546, as its point of departure. It argues that this dictionary, as well as other dictionaries and treatises produced in the wake of Lambrecht's, did more than teach their young audience in the Dutch Republic the meaning of existing words and thus transfer cultural and linguistic knowledge as was already understood. They also taught youngsters how to obtain (new) knowledge from their own empirical observations. The Dutch books on morphology, orthography, phonology, and grammar - produced in large numbers - offered their readers the opportunity to use their own language as an object for empirical study. By charting the dynamics of language, knowledge, and empirical training, it is argued that the Dutch language was, for a short time, treated by writers not merely as a means to express and share knowledge, but also as an object of study in itself. What might have formed an accessible training ground for the development of skills in empirical observation and especially self-reflexive practice, was, however, soon snuffed out by a second wave of tutorial books which emphasised the prescriptive over the explorative.
\end{abstract}

Keywords: knowledge culture, empirical training, linguistic education, youths

DOI 10.51750/emlc.11335 - URL: http://www.emlc-journal.org

Publisher: Stichting EMLC

Copyright: The Author(s). This work is licensed under a Creative Commons Attribution-NonCommercial 4.0 International License. 


\section{Language as an Object of Empirical Study in the Dutch Republic}

\section{ELS STRONKS}

In 1546, Joos Lambrecht's dictionary and language primer Naembouck van allen naturelicken ende ongheschuumden vlaemschen woirden (Dictionary of all original, unappropriated words of the Dutch language) was published. ${ }^{1}$ The book contains Dutch words listed in alphabetic order: all of them ongeschuumd, that is, words not borrowed from any other language. ${ }^{2}$ For each word, a French translation is provided. In his preface to the first edition, Lambrecht wishes 'youths eager to learn French' every bit of success. ${ }^{3} \mathrm{He}$ acknowledges his shortcomings as a teacher, not being a native speaker of French. He states that these limitations might affect the learning process of the young readers, but the inadequate maniere van spelling (orthography) most commonly used in Dutch printed books posed an even bigger didactic problem for him. Common spelling practices did not cater to his need to educate young readers about distincciën: pauses between sounds that are crucial to the correct pronunciation of French. ${ }^{4}$ To solve this problem, Lambrecht created an orthography of his own, which he diligently explained in instructions such as these:

Wherever you find the diphthong 'AE' or 'ae', consider it a feature of the Dutch language, a syllable made up by an 'a' and 'e'; when pronounced, it sounds neither like an 'a' nor 'e', but like something in between. ${ }^{5}$

A point of reference for the young reader is thus their pronunciation of Dutch, and more particularly an attentive observation to their pronunciation. Paying close attention to their natural pronunciation would help them to create the proper French sound in between 'a' and ' $e$ '.

1 The only copy of this book is kept at Museum Catharijneconvent, Utrecht, вмн Warm od255H12. See Cickx-Indestege, 'The first edition of the Naembouck', 13. I include books and sources from the early modern Southern as well as the Northern Netherlands and refer to them (and translate references such as 'Flemish' or 'Duyts') with the overarching, yet modern and thus anachronistic term 'Dutch'. See Lambrecht, Het naembouck van 1562, cxi, for a reason to interpret Lambrecht's vlaemsche in the sense of the modern term 'Dutch'. Unless otherwise noted, all translations are the author's.

2 See for this translation Lambrecht, Het naembouck van 1562, cXI.

3 Lambrecht, Naembouck, sig. A1v: 'Jonghers die beghaerte hebben de Franschoyse tale te leeren'.

4 Lambrecht, Naembouck, sig. A1v.

5 Lambrecht, Naembouck, sig. A2v: 'Dear ghy vind dezen diphtongus AE ae, Dats een dijnck in t vlaemsche, ende es een sillibe van a ende e, ende luudt in tuutspreken noch a noch e, maer half a half e.' 


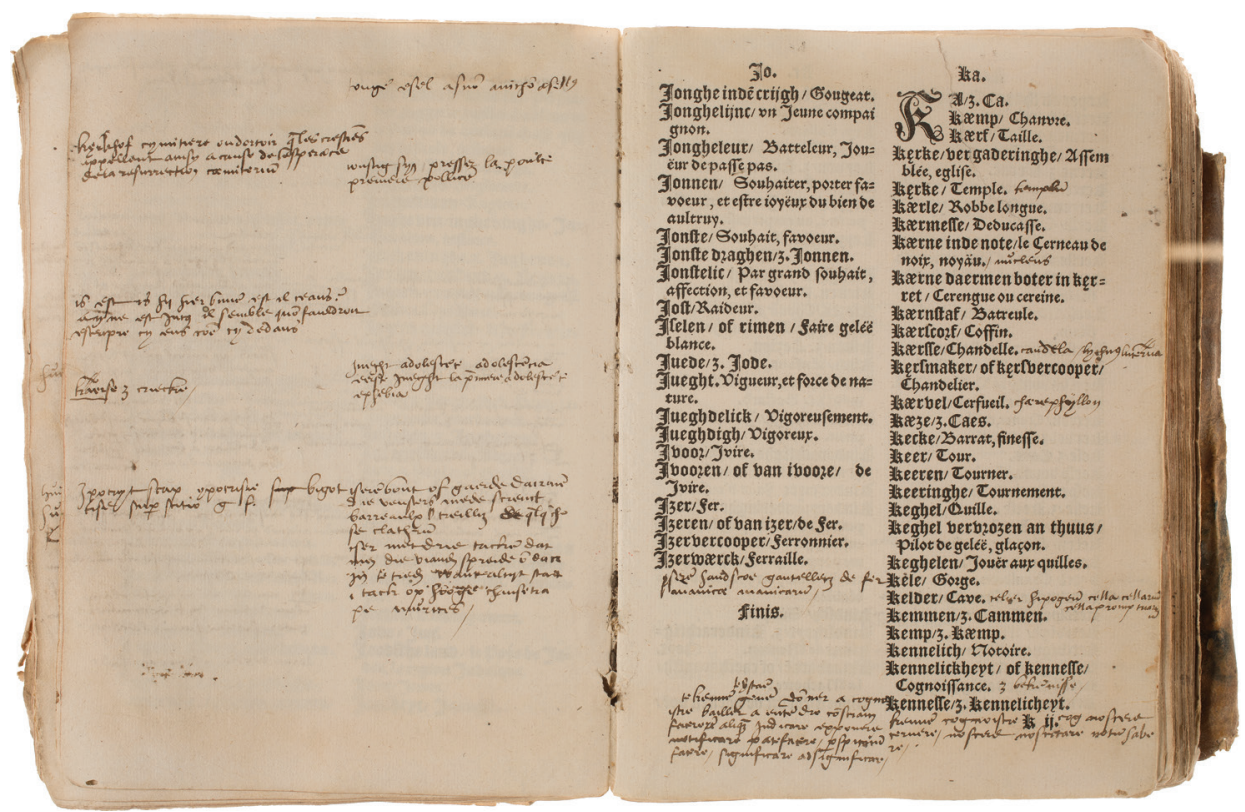

Fig. 1 A used copy of Joos Lambrecht, Naembouck van allen naturelicken ende ongheschuumden vlaemschen woirden by a b c overghezett in walscher tale, Gent 1546, sig. kir, Utrecht, Museum Catharijneconvent. The previous folio has intentionally been left blank on both sides.

Passages like these have thus far been studied as attempts at language standardization and uniformization, as defences of the vernacular languages and their underlying cultures, and as exponents of multilinguistic dynamics. ${ }^{6}$ In this article, I examine how linguistic textbooks intended for Dutch youth such as Lambrecht's Naembouck served to an ever greater extent as invitations to reflect on language as if it were an object one could study empirically.? The young reader's own use of language was represented as an object that could be explored. As I will argue, it was not only didactic techniques and metaphors that turned language into an object that could be studied empirically, but the physical appearance of the textbooks that did so as well. The only known copy of the first edition of the Naembouck is regularly interleaved with blank pages after every printed page, thus stimulating the young to acquire new linguistic knowledge by allowing them to add their own pieces of linguistic information wherever they felt necessary (see fig. 1). In this particular case, it was most likely the buyer of the book who made this adjustment, for the 'paper for interleaving bears a different watermark from the kind of paper used by the printer [i.e., Lambrecht himself]'. ${ }^{8}$ Perhaps the interleaving was commissioned by (the daughter of)

6 Van der Haar, The Golden Mean of Languages, 6-9.

7 In the context of the Dutch Republic, 'youth' implied 'the unmarried'; distinctions were made between children (up to the age of twelve) and young adults (up to the age of marriage). See for instance Dorren, Eenheid en verscheidenheid, 40.

8 Cickx-Indestege, 'The first edition of the Naembouck', 14. 
Claes Touiijons, Lysbet Touiijons, who owned the book in 1552, as indicated by an annotation on the inside of the front cover. ${ }^{9}$

The large number of blank pages allowed for the taking of notes, which the book's owner took ample advantage of. The didactics techniques as well as the physical appearance of the linguistic text books thus spurred empirical study: by this I mean that they encourage young readers to note their linguistic knowledge through the observation of, and even the experimentation with, their own use of language.

The aim of this article is to examine the evolving connection between youth and linguistic knowledge in Dutch textual culture in relation to the transition, in the Dutch Republic, to a more empirically based knowledge culture. The vast corpus of dictionaries, linguistic treatises, and grammars for adults as well as the linguistic textbooks for the younger reader have thus far been studied primarily in order to elucidate the ongoing process of the standardization of the language, the connection between the elevation of the vernacular with the formation of the nation and multilinguistic dynamics. Scholars have focused on linguistic issues such as language variation, grammatical shifts, and lexicographical developments, and, from a more sociolinguistic approach, on linguistic developments resulting from regulation: the effects of formulaic language and letter-writing manuals, for instance. ${ }^{10}$ Other questions have included debates among Dutch scholars such as Johannes Becanus, Abraham Mylius, Josephus Justus Scaliger, and Marcus Zuerius Boxhornius about the comparison of European languages, and on how the Revolt against Spain, the struggle for freedom of (religious) thought, and the desire to contest the cultural hegemony of the French language were all symbolized by the burgeoning interest in the Dutch language. ${ }^{11}$ Although I will use these current findings, this article opts for an approach that sheds light on grassroots developments as prompted by education that meant to gear the minds of the young towards empirical observation of their own use of the Dutch language. The evolving connection between youth and linguistic knowledge in Dutch textual culture perhaps played a specific and perhaps pivotal role in the transition to a more empirically based knowledge culture in the Dutch Republic.

\section{Dutch Dictionaries and Their Young Readers}

In themselves, dictionaries like the Naembouck would seem to restrict rather than encourage searches for unseen treasures and new knowledge. Their alphabetical order suggested and determined a beginning and an end to what was known at the time. However, as scholars such as John Considine have argued, dictionaries also disseminated new knowledge, teaching their readers new words and concepts. ${ }^{12}$ Dictionaries were based on the

9 Cickx-Indestege, 'The first edition of the Naembouck', 15. I have not succeeded in finding any biographical details about her.

10 De Vries, Willemyns, and Burger, Het verhaal van een taal; Ruijsendaal, Letterkonst; Bakker and Dibbets, Geschiedenis van de Nederlandse taalkunde; Rutten and Van der Wal, Letters as Loot.

11 Van Hal, 'Moedertalen en taalmoeders', 475; Van der Haar, The Golden Mean of Languages.

12 Considine, Dictionaries in Early Modern Europe, 11-12. 
humanistic ideal of a distribution of comprehensive, encyclopaedic knowledge, encompassing 'the whole range of the written word', as Erasmus put it. ${ }^{13}$ They also, however, actively enhanced the language by introducing new words. For instance, the Dutch language was enriched with vocabularies for trade, law, science, medicine, architecture, warfare, theology, and government by the recording of words in Johan Hofman's Nederlandtsche woorden-schat (1650). ${ }^{14}$ Dictionaries thus also invited readers to think about language's productivity - its ability to generate new words. Within the restrictive framework of rules, lexicographical and philological interests were often combined in searches for new knowledge, as Dirk van Miert and others have concluded in their examination of the work of the Dutch scholar Hadrianus Junius. ${ }^{15}$

Moreover, as Considine among others has argued, these dictionaries - 'lexical objects', in his terminology - helped to establish new communities because they transferred cultural knowledge. These books allowed readers to visit the linguistic and cultural past as well as the present. An oft-cited example of transfer of cultural knowledge is found in the work of the eighteenth-century English lexicographer and writer Samuel Johnson, who defined 'oats' as 'a grain, which in England is generally given to horses, but in Scotland supports the people'. As Peter Burke has argued, the interest for this type of knowledge prompted the creation of new 'speech communities' and new transregional or superregional loyalties. ${ }^{16}$

Multilingual dictionaries such as Lambrecht's Naembouck were soon followed by other linguistic textbooks that produced even more new linguistic knowledge. They reveal how the exploration of linguistic structure became an important goal. ${ }^{17}$ Robert and Henri Estienne's Dictionarium Latino-Gallicum, printed in Paris in 1531, was one of the first attempts to observe and analyse hitherto unseen grammatical features of language, with the emancipatory aim of defending and elevating the vernacular languages. Estienne, for instance, attempted to grasp the grammatical principles of French in his Traicté de la grammaire française (Treatise on the French grammar, 1557). ${ }^{18} \mathrm{His}$ example was soon followed in other European countries, as evinced by, for instance, Hendrik Laurensz. Spiegel's Twe-spraack vande Nederduitsche letterkunst (Dialogue on the Dutch grammar, 1584). ${ }^{19}$ Together, they formed an interconnected, transnational body of knowledge. In all European grammars (especially the Dutch grammars), Latin rules were followed. But they no longer excluded the pupils' native tongues that were actively used to learn the Latin grammar via translation exercises or through exercises organised according to a new comparative principle: comparing and noting the language known to the pupils with the language they aimed to acquire became one of the most trained

13 Cited in Considine, Dictionaries in Early Modern Europe, 24. See also Walker Read, 'The History of Dr. Johnson's Definition of "Oats".

14 Hofman, Nederlandtsche Woorden-Schat.

15 See in the volume edited by Van Miert for instance Van Hal, 'A Man of Eight Hearts', 196-197.

16 Burke, Languages and Communities in Early Modern Europe.

17 Considine, Dictionaries in Early Modern Europe, 14-15.

18 Estienne, Traicté de la grammaire francoise.

19 Spiegel, Twe-spraack vande Nederduitsche letterkunst. 


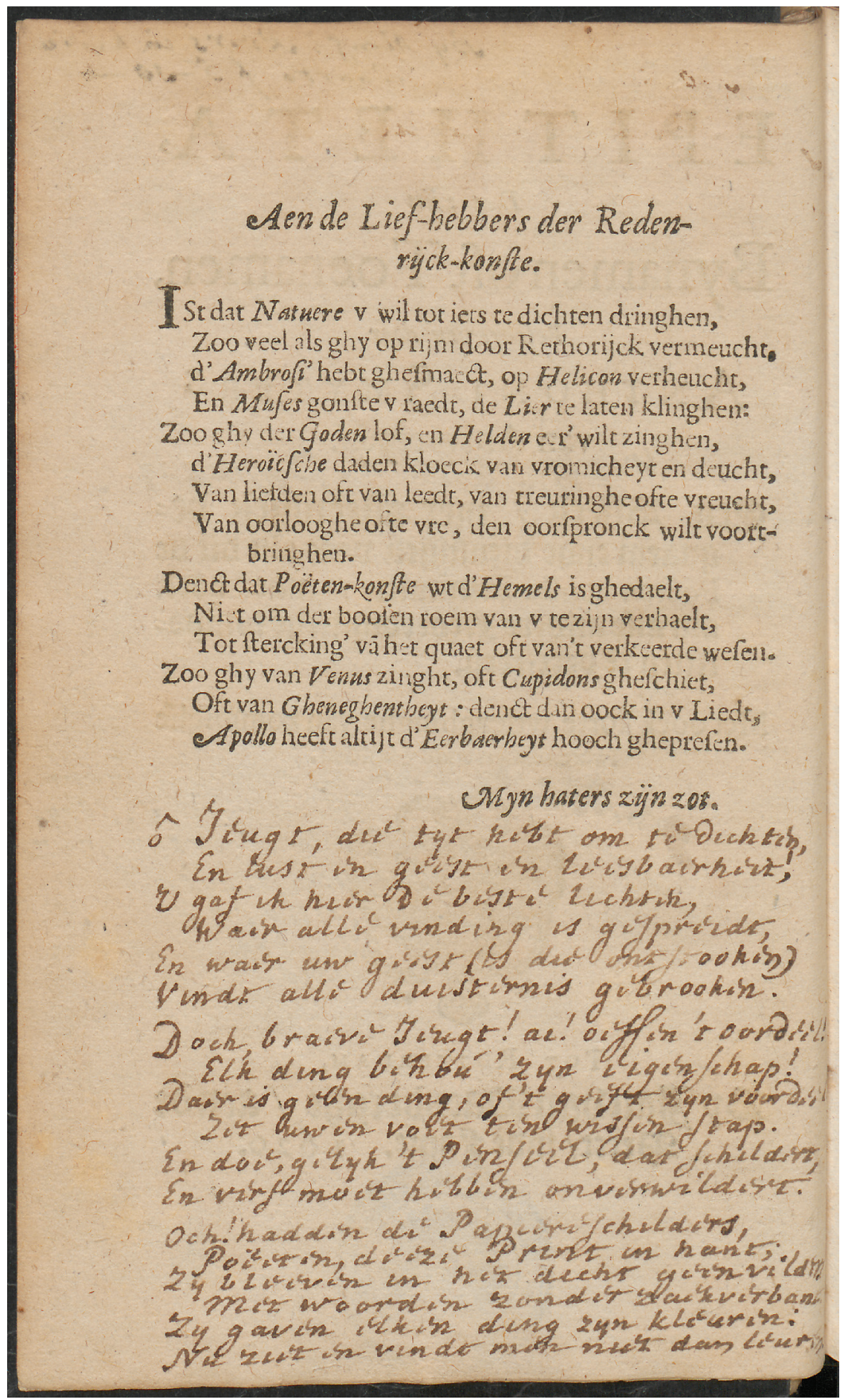

Fig. 2 Preface to Anthoni Smyters, Epitheta, dat zijn bynamen oft toenamen, Rotterdam 1620, 1, with the handwritten poem by Pieter Poeraet. Utrecht, University Library, Special Collections. 
skills. ${ }^{20}$ The 1485 Latin grammar Exercitium puerorum grammaticale (Grammar practice for children), published anonymously in Antwerp, for instance, was grounded in many of the conventions of the Latin medieval grammars, but pupils were instructed to compare the word order in Latin and German languages. ${ }^{21}$

Dutch youth were seen as the target audience of such publications, as is the case in Lambrecht's Naembouck. The book's second edition, published in 1562, articulated this idea even more strongly, as Lambrecht noted that it had been produced 'for the benefit of the youth'. ${ }^{22}$ Christoffel Plantijn's four-language dictionary Dictionarium Tetraglotton, also published in 1562 , was even dedicated to Dutch (Belgica) youth. ${ }^{23}$ In this article, I focus on the publications with similar dedications, and label them as 'youth textbooks'. This label does not apply to dictionaries for adults that drew on material from youth textbooks, such as Hendrik Laurensz. Spiegel's Twe-spraack, for which Spiegel used cases from the Exercitium puerorum grammaticale. It does also not apply to books written by authors who presented themselves as schoolmaster and the dictionary or treatise as the result of their teaching practices, as did Anthoni Smyters in the preface to his Epitheta, dat zijn bynamen oft toenamen (Epitheta, that is, adverbs or nicknames, 1620). ${ }^{24}$ Perhaps young readers were also the main audience of these publications. The copy of Smyters's dictionary kept in the library of Utrecht University demonstrates how one of his readers, the Dutch minister Pieter Poeraet, added a handwritten poem that affirms the idea. In this poem, Poeraet urges the Dutch youth to take notice of Smyters's excellent work: 'Oh youth, with time on your hands to write poetry' (fig. 2). ${ }^{25}$ Because reports that these books were employed by young readers are merely anecdotal, however, I have chosen not to include them in my corpus.

\section{Linguistic Textbooks for Dutch Youth as Product of a Trading Zone}

Linguistic textbooks intended for Dutch youngsters could have a societal impact on Dutch knowledge culture for a number of reasons. First, they were produced in large numbers, given the tendency towards the use of the vernacular in the Dutch Republic educational system. Pleas for the use of the vernacular in universities were made relatively early. Amsterdam tried to persuade the University of Leiden - the first university in the Dutch Republic, founded in 1575 - to use Dutch as its official language from the very start. When

20 Harun, 'Latin Influence in Early Malay Grammars', 9. See also Kok, Ont-werp der Neder-duitsche letter-konst, XXI-XXII.

21 Rener, Interpretatio, 114-116; Bakker and Dibbets, Geschiedenis van de Nederlandse taalkunde, 20.

22 Lambrecht, Het naembouck van 1562, frontispiece: 'tot voorderinghe van der jongheyt'.

23 In the preface to his Dictionarium tetraglotton, Plantin claimed to have published the book 'to make sure that all children in Belgic Gaul (Gallium-Belgium) have access to a dictionary in their own language', as cited in Sterkenburg, Van woordenlijst tot woordenboek, 31. See also Langereis, De woordenaar, 70; Waterschoot, 'Antwerp', 233-249. Plantin's dedication was perhaps inspired by Robert Estienne's Dictionariolum puerorum, published in 1542. In 1564, Plantin produced the Promptuarium Latinae Linguae as an intentional follow-up to Estienne's work. See De Neve, 'Aantekeningen over 16de-eeuwse lexicografie', 201.

24 Smyters, Epitheta, 2-3. See also Van der Sijs, Het versierde woord.

25 Smyters, Epitheta, dat zijn bynamen oft toenamen, 1: 'O Jeugt, die tijt hebt om te dichten'. 
these attempts failed, in 1617 Amsterdam established its own Nederduitsche Academie (Dutch Academy), with Dutch as its official language. ${ }^{26}$ Their argument was not only that it would serve to bolster the status of the vernacular, but also that it would serve to made education more efficient. For instance, in the preface to Spiegel's Twespraack, the philosopher Dirck Volkertsz. Coornhert explains how much time would be saved if Dutch rather than Latin were part of the trivium (grammar, logic, and rhetoric - the lower division of the seven liberal arts). This change would particularly benefit 'eight-year-old boys', because 'their minds would be just as well equipped for all branches of science as the minds of fourteen-year-old boys that have been steadily tortured at the rack of the Latin grammar'. ${ }^{27}$ This argument continued to be made for several decades. The Dutch physician and author Lodewijk Meyer would repeat it in the 1658 preface to the third edition of his Nederlandsche woorden-schat:

A great number of years and effort dedicated to the acquisition of the Latin language would be saved and used for a better purpose. [...] The youth should not be obliged to spend nine to ten years chasing and hunting down the knowledge of a language. ${ }^{28}$

Second, not only boys but also girls were included in these sorts of initiatives, and this also counted towards the number of textbooks produced. A 1599 publication by the female schoolmaster Magdaleine Valery - designed to both enlarge the vocabulary and hone the rhetorical skills of young female pupils - shows how sometimes textbooks were produced that explicitly targeted girls as their audience (fig. 3). ${ }^{29}$

Based on how many sixteenth- and seventeenth-century Dutch linguistic textbooks were produced with the intention of using them at schools where Dutch was the language of instruction, as well as the number of children and young adults who attended schools and learned how to read, one can surmise that a relatively large group of children and young adults was affected by vernacular linguistics textbooks. ${ }^{30}$ The textbooks dedicated to Dutch youngsters offered knowledge about orthography, prosody and phonetics (the patterns of stress and intonation in a language), etymology and semantics, and syntax. ${ }^{31}$ They also constitute a significant part of the overall book production in the Dutch Republic. ${ }^{32}$ The Short-Title Catalogue Netherlands (STCN) and the Short-Title Catalogue Vlaanderen (STCV) together list 135 titles of textbooks aimed at Dutch youth printed between 1527

26 Kok, Ont-werp der Neder-duitsche letter-konst, xxiII.

27 Cited in Gelderblom, “'Nieuwe stof in Neerlandsch"', 104-105: 'jongskens van acht jaren'; 'zulx dat hare verstanden niet min dan nu jonghers van veerthien jaren (na de langhdurighe pynbancken der wetten vande Latynse tale) bequaam zullen wezen tot alle ghoede kunsten'.

28 Kok, Ont-werp der Neder-duitsche letter-konst, xxvi: 'zoude een lange reeks van jaaren, moeyten, en onkosten, die men an't leeren der Latijnsche taal hangt, ghespaart, en te kost gheleidt konnen worden. [...] Der Jonkheidt zoude het niet noodtzaaklijk zijn, neeghen oft tien jaaren om de kennis der taalen te bejaaghen, te verslijten.'

29 Van der Haar, 'Van "nimf" tot "schoolvrouw".

30 Both literacy rates and the percentage of the population with primary and secondary education were relatively high in comparison to other European countries, especially in the Dutch Republic: Frijhoff and Spies, Dutch Culture in a European Perspective, 105, 236-257.

31 See for an overview Bakker and Dibbets, Geschiedenis van de Nederlandse taalkunde, 51.

32 The production rate of books was also relatively high in the Dutch Republic: Buringh and Luiten van Zanden, 'Charting the "Rise of the West"'. 


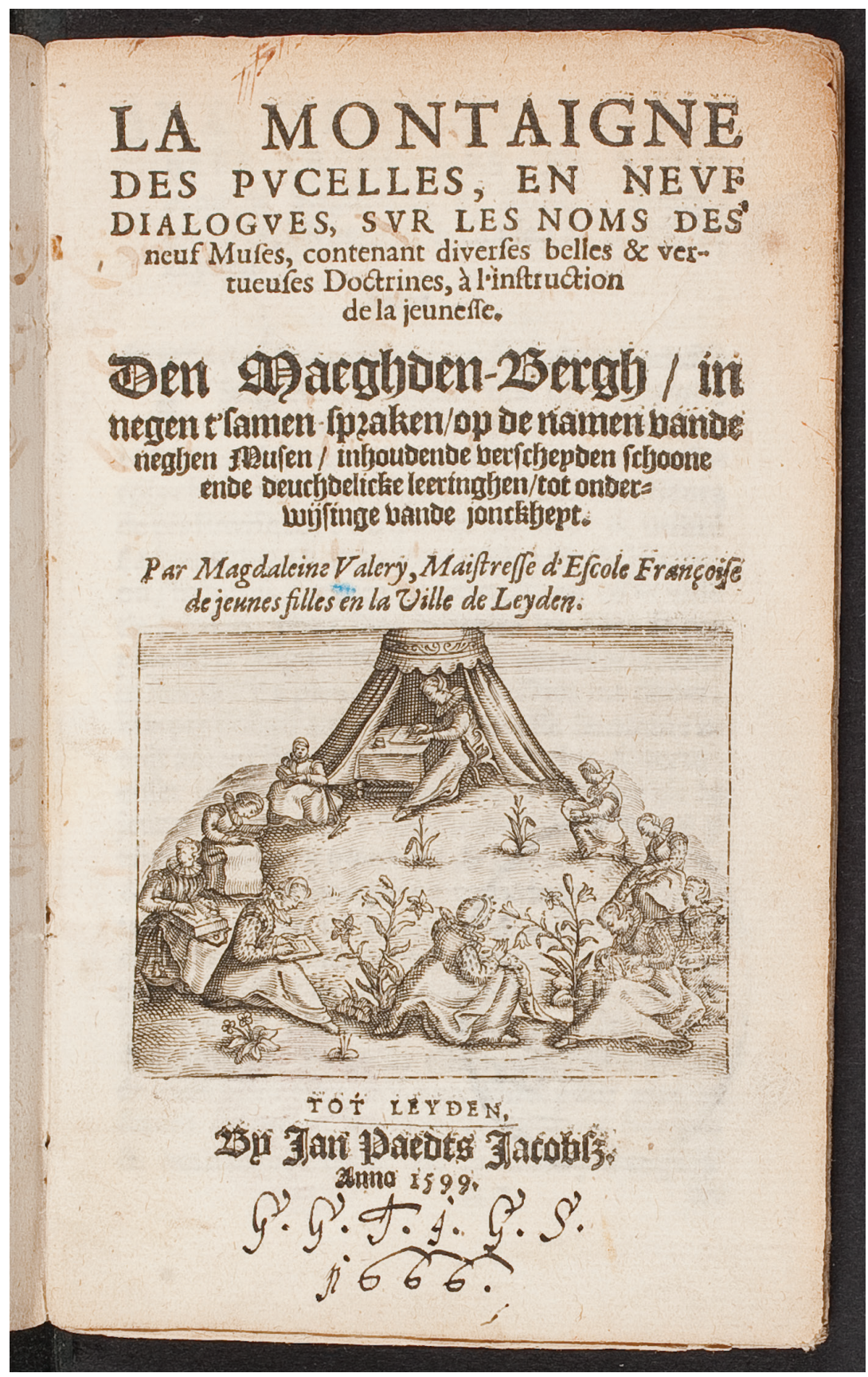

Fig. 3 Title page to Magdaleine Valery, La montagne des pucelles, en neuf dialogues, sur les noms des neuf muses./ Den maeghden-bergh, in negen t'samen spraken, op de namen vande neghen Musen, Leiden 1599, Wolfenbüttel, Herzog August Bibliothek. 
and 1750 . Out of these 135,86 are dedicated to linguistic education (whether dictionaries, linguistic treatises, or grammars). ${ }^{33}$

The scope of this article is very broad, dealing with sources from the sixteenth to the eighteenth centuries. I will therefore focus on trends rather than on specific titles. The Nederduydsche spellinge (1612) by Jacob van der Schuere, for instance, will not be discussed, although the case supports my argument: the book presented a new spelling system that required young readers to explore their own use of language because it was based on the idea 'that one writes all words, as much as possible, as one pronounces them' ${ }^{34}$ Yet his case yields no new insights into the innovation disclosed by my discussion of Lambrecht's Naembouck. Rather than exploring multiple similar cases, then, this article focuses on wider trends that developed over time. The first key development was that once a frontrunner like Lambrecht had put a system in place and had developed didactics (be it for orthography, phonetics, or grammar), subsequent textbooks revolted against 'the existing, crippled system' established by previous textbooks, as Van der Schuere put it. ${ }^{35}$ This would suggest that Dutch textbooks continued to be experimental in nature, requiring young readers to use their empirical observations. The second key development, however, was that the more descriptive approach to language prevalent in the first textbooks on orthography, phonetics, and grammar - and which left ample room for the young reader's empirical observations - were slowly being replaced by an increasingly prescriptive approach to the writing and speaking of Dutch. Yet even this prescriptive approach still had the exploratory young reader in mind: the object of study (language) required young readers to observe their own use of language in order to make progress.

In this article, I approach the massive amounts of linguistic textbooks, and the intergenerational and intersectional dynamics they entailed, as products of a 'trading zone' - a concept developed for the study of modern history of science by Peter Galison, and made applicable to the history of early modern science by Pamela Long. ${ }^{36}$ They have defined trading zones as arenas in which substantive and reciprocal communication occurred between artisans with hands-on training on the one hand and university-trained individuals on the other, which resulted in the creation of new knowledge. As Long has argued, 'the mid-sixteenth century was an era before the development of modern professionalism and its hyperspecialization. It is precisely this preprofessionalism, the lack of standard training, educational, and licensing requirements for, say, architects and engineers (who were often also called architects) that contributed to the development of trading zones. ${ }^{37}$ Even though the professionals who crafted the textbooks were not artisans, I would argue they helped to create a trading zone as well - a linguistic trading zone, to be precise. Lambrecht was a prototypical exponent of the type of individuals

33 These selections were made using the keywords 'education' and 'Dutch language and culture' in both catalogues. I have labelled them as 'intended for linguistic education'. Not included in this count are catechisms aimed at youths.

34 Van der Schuere, Nederduydsche spellinge, 33: 'datmen alle woorden, zoo verre alst muegelijk ware, alzoo schreve alsmenze uyt-sprekt'.

35 Van der Schuere, Nederduydsche spellinge, 4: 'd'oude kruepele gewonte'.

36 Galison, Image and Logic; Long, 'Trading Zones'.

37 Long, 'Trading Zones', 843. 
Galison and Long have in mind as creators of a trading zone: in addition to being a printer, typecutter, and engraver, he was also a schoolmaster and linguist. ${ }^{38}$ Van der Schuere also operated in the worlds of academic knowledge, of painting (he was a good friend of the painter Carel van Mander), and of printing and mediated between them. The commixture of artisans and professionals led to the creation of new knowledge: teaching linguistic knowledge to Dutch youth implied the production of new linguistic fault-lines for the vernacular languages.

\section{The Experimental Phase in the Creation of Linguistic Knowledge}

As seen in the preface of Lambrecht's Naembouck, attempts to unify Dutch spelling lay at the root of the first linguistic textbooks. In the preface to the second volume of the Nederlandsche spellijnghe (1550), this unificatory urge did not imply that language variation would be minimized. Lambrecht explained how he aimed to offer a uniform, phonetic spelling system for all the variants of Dutch spoken at the time: in principle, all similar sounds should be signified by similar spelling, 'so as to ensure that from now on, all youngsters are taught the same in schools where Dutch is the official language' ${ }^{39}$ Lambrecht's aim was not to unify Dutch as a language, because he regarded all variants of Dutch to be of equal value. Rather, he wanted the same sounds in all variants to be spelled the same way. To achieve his ideal of 'one letter for one sound', he introduced new characters and letter combinations such as ' $\varrho$ ' and ' $\notin$ ' into the Dutch alphabet. ${ }^{40}$ In this way, he hoped to create a system in which everyone might be able to write down and transcribe any sounds he produces when speaking their mother tongue..$^{41}$ His manual is set up as a dialogue between a pupil and a master - modelled after a number of existing orthographies on other languages..$^{42}$ This didactic format leaves room for clarifications, questions, and objections that allow pupils to grasp the essentials of their study object. It becomes obvious through the roles of pupil and master that acquiring knowledge about the spelling of one's own dialect or variant according to a uniform spelling system for the Dutch language as a whole can be achieved only through the exploration and scanning of one's own use of language.

Lambrecht's ideological and didactic approach asserted that young readers could use the textbook regardless of their dialect: he addressed their ability to observe their own language use. What Lambrecht offered was not a fixed and prescriptive normative spelling system. Since his starting point was not - and could not be, at that point in time - a standardized Dutch language, he presented a relatively open, descriptive system. The application of this system required previous (prescriptive) knowledge about vowels, consonants, pitch, tone, intonation, timbre, and parts of speech. Although the system itself was non-prescriptive, it required prescriptive knowledge to inspect one's own language.

38 Cickx-Indestege, 'The first edition of the Naembouck', 14. See also See Waterschoot, 'De Gentse drukkers', 27. 39 Lambrecht, Nederlandsche spellijnghe, 4: 'op dat van nu voordan/tzelfde in alle scoolen van Nederlandscher sprake/den ionghers zoude moghen voorghehauden ende onderwezen werden'.

40 Bakker and Dibbets, Geschiedenis van de Nederlandse taalkunde, 24-25.

41 Lambrecht, Nederlandsche spellijnghe, 4.

42 De Keyser, 'Bronnen van Joos Lambrechts Nederlandsche Spellijnghe', 1352. 
For instance, one should be able to distinguish ' $i$ ' and ' $j$ ': the ' $j$ ' had to be spelled as an underlined ' $i$ '. ${ }^{43}$ To do so, one should be aware that the ' $i$ ' could stand for a vowel as well as a consonant, and one should also be able to distinguish between letters that you can hear and letters that have no audible sound:

\begin{abstract}
Pupil: What are vowels?
Master: Those are the letters you will always hear; there is not one word that is spelled without a vowel; but vowels in themselves can constitute a word. The vowels are: a, e, i, o, u. Among the vowels, there are two that can metamorphose into a consonant: the ' $i$ ' and the ' $u$ '. The $i$-consonants are signified by a dot, so one should teach that the vowel ' $\mathrm{l}$ ' is the single letter ' $i$ '. 44
\end{abstract}

As he did in the Naembouck, Lambrecht suggested that a comparison with vowels in other languages might help the analytical process, for instance in gaining an understanding of diphthongs, two adjacent vowels: 'the Greek call those syllables "diphthongs". In our language these are the sounds constituted by two vowels. We, the Dutch, however, do not only use diphthongs, but also sounds made up of three or four vowels. ${ }^{35}$ Not only do the sounds one produces need inspection to apply Lambrecht's system correctly. Certain words can be spelled correctly only if the author can make an analysis of parts of speech:

Pupil: teach me then how to create words out of vowels, and how one should discriminate.

Master: When those five vowels mentioned earlier by themselves constitute a word, one should add an accent grave, to get this: à. è. i. ò. ù. An example: 'A Peter, are you there? The 'a' is not a letter but a word in this clause, also named interjectio applaudentis, that is an interjected part of speech that expresses a speaker's joy. ${ }^{46}$

This is in fact a rare case in which Lambrecht is prescriptive, when he limits the choice of an interjected part of speech to the five vowels he lists. In all other instances, choices in the use of words are left to the reader.

Such openness is also found in the first textbook on phonetics: intellectual and experimental effort was needed when the object of linguistic study was new, not only to the reader but also to the author. In 1635, Petrus Montanus published his Bericht van een niewe konst, genaemt de spreeckonst (Message regarding a new art, called the art of speech, 1635), the first textbook on the phonetical exploration of the Dutch language. ${ }^{47}$ Being a minister, Montanus indented this textbook to be used by school masters at Duitse schoolen

43 Sijs, 'Joos Lambrecht'.

44 Lambrecht, Nederlandsche spellijnghe, 10-11: 'L[earling]. Wat zijn vocâles? M[easter]. Dat zijn ludēde, sprekēde, of voais gheuēde letters: zōder de welke mē ghean sillebe noch woord op zijn recht spellē en magh noch en cā: ia ean vocale allean maakt zōtijds eā sillebe of woord: zoamen hier naar noch beụinden zal ende zijn deze: a., e., i., o., u. Van den welken zijnder twea die zomtijds veranderen in consonātes, te wetē i eñ u. De i consonans hebbe ic ōderteakēd met eā stipki aldus ị eñ die zalmē dē Jōghers learē name ijnkel i.'

45 Lambrecht, Nederlandsche spellijnghe, 43: 'Die silleben heaten de Grieken diphthongos, dat zijn by ons vocaal silleben van twea ludende letters ghemaakt. Maar wy Nederlāders en hebben niet allean vocaalsil leben van tweā alleane tzy ghelike of onghelike: maar van dry eñ vier vocalen ghemaakt.'

46 Lambrecht, Nederlandsche spellijnghe, 13: 'L. Maact my van ghelikē wijs hoe eñ waar de vijf voornaamde vocaal letters woorden maken: ende hoe men die onderscheaden zal! M. Als de voornaamde vijf vocaal letters woorden beteakenen, dan zalmer den accentum grâuem op zetten aldus: à. è i. ò. ù. Exempel. A Pieter, zy dy daar? a en es hier ghe ā letter, maar eā woord, te wetē interiectio applaudētis, dats eā tuschēgheworpē woord der reden vā iemā die eanen anderē blide siere toaght.'

47 Bakker and Dibbets, Geschiedenis van de Nederlandse taalkunde, 60. 


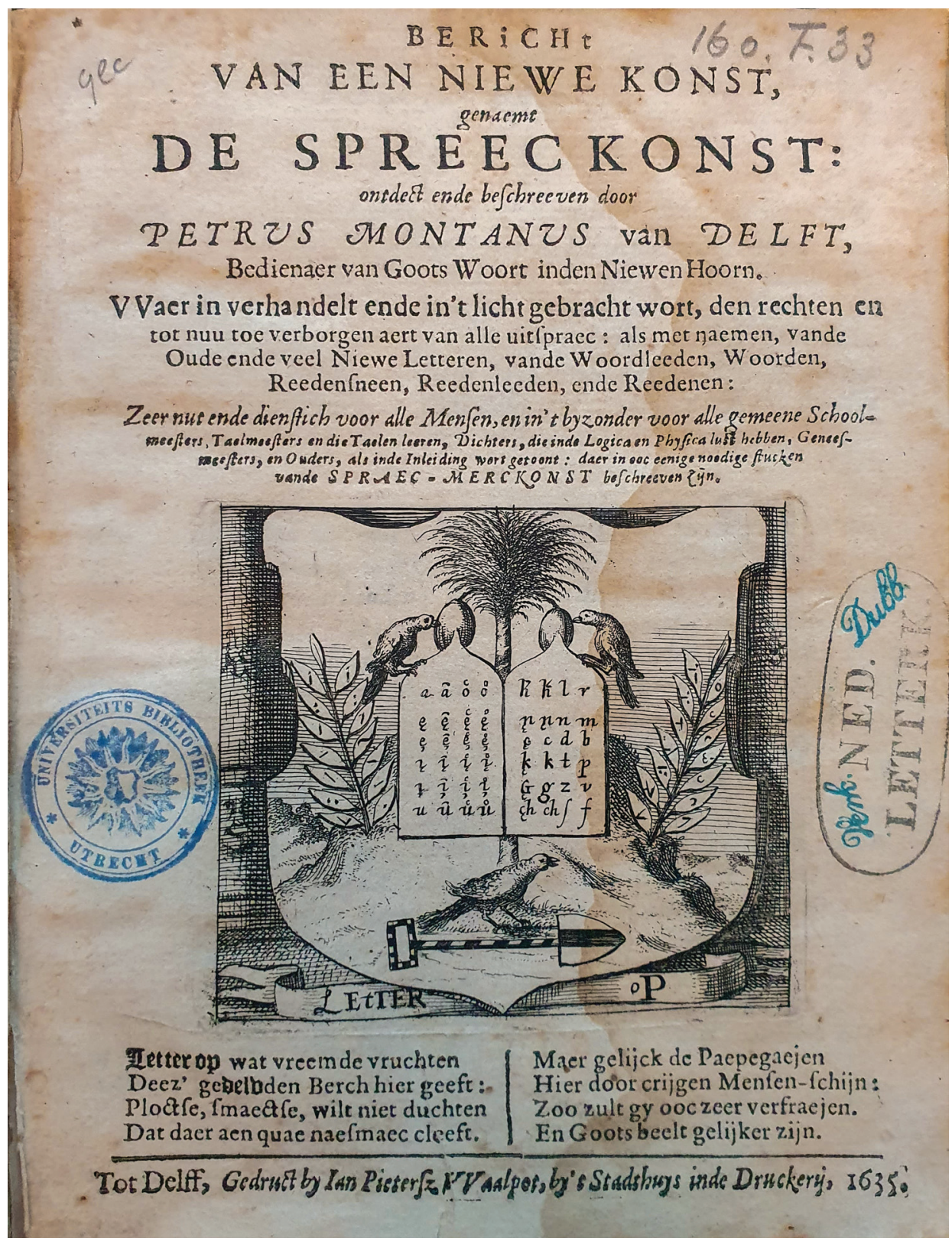

Fig. 4 Title page to Petrus Montanus, Bericht van een niewe konst, genaemt de spreeckonst, Delft 1635, Utrecht, University Library, Special Collections. 
(schools where Dutch was the official language)..$^{48}$ As the illustrated title page (fig. 4) and accompanying poem demonstrate, knowledge of the language will bring humans closer to God: 'Just as parrots appear to become more human, you will be more adorned and become closer to God's image.' 49

From the fruits of the palm tree sprout consonants and vowels, depicted on two boards that resemble stone tablets, in what is possibly an allusion to Luke 6:44: 'For every tree is known by his own fruit.' ${ }^{\circ}$ The spade suggests that Montanus's book can uncover the roots of that tree. Below the spade is the coat of arms of Delft, Montanus's birthplace - which makes him a Delver (researcher, litt.: digger). ${ }^{51}$ The textbook is intended for 'the right and timely education of youth'. ${ }^{22}$ As Montanus wrote, 'whoever is eager to learn about God through the study of what He created, and to find His praise and honour in what He created, should pay attention to the true nature of language'. ${ }^{53}$ In the textbook, pupils could find Ramist-like schedules and schemes that would help them decipher the phonetics of the Dutch language. ${ }^{54}$ Montanus hoped that these tools would speed up the process of learning how to read and write, and thus allow more time for biblical and spiritual education. ${ }^{55}$

In the preface to his textbook, Montanus announces that he has mapped a new domain of knowledge. Not grammar, rhetoric, or poetics, but a domain that we now call phonology or phonetics:

This terrain was neglected and therefore shrouded in the mist of ignorance; but from now on, it will be brightened by the glance of order and insight into causality. Whatever is discovered by this glance does not resemble what we once knew. There is every right to say it is new knowledge. ${ }^{56}$

Montanus argues that his research had yielded new linguistic knowledge, but often when stumbling on dilemmas he had to settle for the most probable solutions: 'In short, I just want to explain that I did not make up anything, but every issue caused a lot of deliberations. I doubted the outcomes of these deliberations long enough to be sure that, in the end, I was able to grasp the truth.' 57

48 Montanus, Bericht van een niewe konst, fol. $2 \mathrm{r}-\mathrm{v}$.

49 Montanus, Bericht van een niewe konst, title page: 'Maer gelijck de Paepegaejen/Hier door crijgen Mensenschijn:/Zoo zult gy ook zeer verfraejen./En Goots beelt gelijker zijn.'

50 Hulsker, Petrus Montanus, 54-55.

51 Hulsker, Petrus Montanus, 56.

52 Montanus, Bericht van een niewe konst, fol. 2r: 'rechte en spoedige onderwijzing der Jeugt'.

53 Montanus, Bericht van een niewe konst, 6: 'Wie dan begeerich is, een Schepper uit zijn werken/Te kennen, en zijn lof en eer daer in te merken/Die dient te Letten op den rechten aert der Spraec.'

54 Hulsker, Petrus Montanus, 112-113.

55 Montanus, Bericht van een niewe konst, fol. $2 \mathrm{v}$.

56 Montanus, Bericht van een niewe konst, 7: 'Zo verwert en onvolkoomen ontdect was, dattet gelijc als met een donkere neevel van onweetenheit omvangen lach: en van nu met een klaeren glans van orde en oorzaekelijke kennis zoo verlicht, dat het geene men nu daer in van niews ziet en weet, ongelijc meer is, alst geene te vooren daer van bekent was: en ten dien aenzien men recht mach gezeit worden van niews gevonden, en ontdect te zijn.' 57 Montanus, Bericht van een niewe konst, 8: 'Daer van ic nu om cortheit alleen zegge, dattet zelve is geschiet, niet seffens, maer by stucken, met dan 't een, dan 't ander te verzinnen: en in elc stuc veel strijdige bedenkinge te hebben: en daer uit't waerschijnlijckste te verkiezen: en dat zoo lang los en in twijfel te stellen, tot dat ic bevon de waerheit recht getroffen te zijn.' 
He then explains why knowledge of phonetics is valuable: it not only allows one to become acquinted with God (for all language was created by Him), but also improves one's use of language and aids in the acquisition of any (foreign) language. In addition, poets profit, as do physicians, for they now understand how sound is produced. ${ }^{58}$ Finally, Montanus explains how the knowledge he wants to convey can best be taught:

With regards to one's study: it should start with the careful reading of what has been written. Once the reading is done, one should immediately start some experiments: pronounce the letters, and examine and compare them to establish differences and similarities. One should put one's finger in one's mouth, to find out how sounds are formed. If the study is not accompanied by this, and just consists of reading and no effort is made to explore, one will find that not much is learned and eveything remains unclear and hard to learn. ${ }^{59}$

Petrus Montanus's Bericht van een niewe konst thus makes apparent that his linguistic textbooks required an inquisitive attitude. Acquiring knowledge of Dutch phonetics was deemed impossible without the study of one's own use of the Dutch language.

\section{The Prescriptive Phase in Creating Linguistic Knowledge}

Such an attitude became less of a prerequisite once a system for Dutch spelling or phonetics was in place. A few decades after Lambrecht had done his pioneering work, the author and canon Pontus de Heuiter published his Nederduitse orthographie (Dutch orthography, 1581), which was based on the principle of a koine, a standardized form of Dutch based on the most excellent elements found in the dialects of Holland, Brabant, and Flanders. ${ }^{60}$ In the preface, Pontus's half-brother Jason urges the (young) reader to acquire the skill of spelling properly:

Working hard is the key to it all, and especially youth should strive to work hard because diligence brings joy to whomever gives an ear to her. So if you feel like it, learn how to properly write and spell and find joy in your heart while doing so. ${ }^{61}$

In this orthography, the sounds of vowels and consonants are presented as miracles that 'high, middle, and low pitches' are able to capture and so facilitate the transfer of thoughts and ideas. ${ }^{62}$ Language thus materializes what would otherwise be non-tradeable and abstract.

58 Montanus, Bericht van een niewe konst, 9, 10, 12.

59 Montanus, Bericht van een niewe konst, 15: 'Aengaende de Onderzoeking, die moet geschieden met de Beschrijving vlijtich en aendachtich te ooverleezen: en by het leesen te voegen de daedelijke ondervinding en beproeving van de beschreeve zaken: mits die uit te spreeken, en daer niet alleen met de ooren naew op te letter, en d'eene teegen d'andere te vergelijken, om haer verschil en oovereencooming te bemerken; maer ooc met een vinger te voelen inden mont, om de gestalte der Vormen beeter te verneemen. Want in gevalle iemant deeze beschrijving alleen ooverloopt, en zonder lust inziet, of daer geen merkelijke tijd en moeite aen besteet: zal geen of weinich vrucht daer uit trecken, en hem alles duister en zwaer schijnen.'

60 De Heuiter, Nederduitse orthographie.

61 De Heuiter, Nederduitse orthographie, 4: 'Naersticheit is die mouder van alle deuht/Die haer niet behoort te schamen die ionge ieuht;/Want zii stiht en breingt die zelven tot vreuht/Al die haer gehoor geven. Dus zo ghii meuht/Maect wel te schriven en spellen dat thart verheuht.'

62 De Heuiter, Nederduitse orthographie, 5: 'door hooh, laeh, ende middelbaer geklainc'. 
This ideology turns spelling into a heartfelt, intellectual exercise that would leave ample room for young readers' individual exploration of their use of language. Rather than analysing the sounds they produce or reflecting upon the meaning they attribute to the words chosen, however, readers of De Heuiter's orthography should simply follow the instructions for correct pronunciation provided in this treatise. De Heuiter's ideology thus allows for individual exploration, but the didactic techniques he applies required mere memorisation.

This turn to a more normative rather than explorative approach is indicative of other linguistic textbooks published in the late sixteenth, seventeenth, and early eighteenth centuries, such as the Neder-duytsche letter-konst (1588) by the schoolmaster Pieter de Berd. ${ }^{63}$ Similar textbooks include the aforementioned Nederduydsche spellinge (1612) by Jacob van der Schuere, De Nederduytsche grammatica ofte spraec-konst (1625) by Christiaen van Heule, the Grammatica ofte leez-leerlings steunsel naar de Onder-wyzinghe des fondaments der Neder-duytscher orthographie (1627) by Richard Dafforne, and the Oprecht onderwijs van de letter-konst (1639) by Cornelis Dircksz. van Niervaert. ${ }^{64}$ In the Letterkonst, sijnde het eerste deel van de Neederlandse spraakkonst (Orthography, or, the first part of the Dutch grammar, 1683) by Wigardus à Winschooten, the first section is devoted to 'the exploration of the features of letters in our alphabet'. ${ }^{65}$ This exploration, however, occurs under Winschooten's strict guidance: exploration is a way of discovering something already known rather than as a mode of knowledge production. For instance, regarding the ' $i$ ', he writes:

Tell me, what is the reason that one should write Leijden instead of Leiden, steijl for steil? What other reason can there be than that the sound 'ei' has been changed and dimmed so that 'ey' was swapped with 'ei.'.6

The purpose of Winschooten's textbook is no longer exploration, such as was the case with Lambrecht, but to eliminate all possible causes of confusion:

Two major obstacles manifest themselves for pupils who are learning any language, namely the double meaning words can have, and uncertainty about their pronunciation. Therefore, before we begin to elaborate on the words, we must first remedy these uncertainties and second, explain what the natural syllables are (as far as possible). ${ }^{67}$

Memorization rather than exploration is advised to tackle the problem of insecurity among students. In his textbook, Van Niervaert included a school prayer for daily recitation by pupils, training them to ask 'O Lord! [...] Affirm our memory with Your strong Hand./ So that we may remember what is planted in us.' ${ }^{68}$ The best way to teach, Van Niervaert

63 Bakker and Dibbets, Geschiedenis van de Nederlandse taalkunde, 32.

64 Van Heule, De Nederduytsche Grammatica ofte Spraec-konst; Dafforne, Grammatica ofte leez-leerlings steunsel; Van Niervaert, Oprecht onderwijs van de letter-konst.

65 Winschooten, Letterkonst, 26: 'het ondersoek van de eigenschap der Letteren in ons gewoonelijk A B'.

66 Winschooten, Letterkonst, 15: 'seg mij eens, wat reeden is' er dat men moet schrijven Leijden voor Leiden, steijl voor steil? wat reeden anders, als dat men de klank van ei heeft verdoofd en veranderd in de ey voor ei?'.

67 Winschooten, Letterkonst, 34: 'Twee groote hinderpaalen sijnder voor de Leerlingen in alle Taalen, naamendlijk, de dubbelsinnigheid der woorden, en de onseekere uitspraak der selve: en daarom eer wij koomen tot het verhandelen der woorden, soo sullen wij eerst oplossen de oorsaak van deese dubbelsinnigheeden: en ten tweeden aanwijsen in wat Lettergreepen de naatuurlijke klank der woorden (soo veel ons moogelijk geweest is) te vinden is.' 68 Van Niervaert, Oprecht onderwijs van de letter-konst, sig. A5r: 'O Heere! [...] Bevestigt ons memorie door u sterke hand./Om welk te onderhouden 't gene in ons wert geplant.' 
explains, is to have the pupils recite in couplets: 'When the prayer is done, the reciting should begin. ${ }^{69}$ If we compare these seventeenth-century textbooks with Lambrecht's Néderlandsche spellijnghe from 1550, it becomes obvious that the tendency is to minimize the pupil's own, active search for the correct spelling of Dutch words.

The acquisition of the linguistic knowledge of spelling, though represented no longer as an inquisitive but rather as a normative process, is still presented as a stepping-stone to the empirical acquisition of knowledge, first and foremost because Dutch was - like any language at the time - to a certain degree unruly. In practice, even though there was a prescriptive aim and ideology of unification, for instance in textbooks on orthography, pupils had to reflect on their own use of language to spell and write correctly, especially if using a dialect not integrated into the slow development of standardized Dutch. And some of the reader's attention was still focused on the production of sound, as is evident from the preface to Van Niervaert's Oprecht onderwijs van de letter-konst:

Please notice carefully what is explained in the next section, and learn about the power and resonance of the letters: observe what each letter represents, or what a pair of letters produces, what the 'e' or 're' does, how the ' $i$ ' and the ' $j$ ' differ, what sound the 'o' or 'vo' produces, and when the 'u' or 'v' or ' $w$ ' are used. $^{\circ \circ}$

Linguistic knowledge enables children to read, and thus learn about explorations others have made as well as the knowledge that resulted from these explorations as conveyed in printed texts. This argument is made on Dafforne's engraved title page (fig. 5) through a quotation from Spiegel's Hartspiegel (Mirror of the Heart): 'Take notice: A child who has poor knowledge of the letters, or skips the lessons about spelling correctly, will read poorly for the rest of his life. ${ }^{71}$ Being able to read well allows one to acquire any knowledge, to be acquired at one's own effort and according to one's own interest. As Van Heule puts it in his preface: 'The benefit the reader will get from this book is, in the end, a thorough knowledge of all words and sentences that open up the way or the door to all sciences. ${ }^{72}$ Van Niervaert made a similar argument in his Oprecht onderwijs van de letter-konst: 'Learn how to read and write when you are young, spare no money or effort, for the unlearned have to succumb to the learned. ${ }^{73}$ Acquiring a properly spelled vocabulary of one's own was thus presented as an investment that would allow one to succeed in life.

69 Van Niervaert, Oprecht onderwijs van de letter-konst, sig. A6r: 't Gebed gedaan zijnde, zal men beginnen op te seggen'.

70 Van Niervaert, Oprecht onderwijs van de letter-konst, sig. A4v: 'Merkt nu wel neerstelyk op 't gene hier volgt, ende leert de kragten ende resonnantie der Letteren, wat een Letter doet, ofte wat twee Letteren doen konnen, wat e ofte re doet, wat i ofte y ofte ij verschillen, wat o ofte vo voor klank hebben, en wat men met u ofte $v$ ofte w spellen kan.'

71 Van Heule, De Nederduytsche Grammatica ofte Spraec-konst, title page: 'Nota: Een kind dat letters leert, verkeert, oft' dat versma'lyk/Twel-spellen overslaat: leest all'zyn leven qualyk.'

72 Van Heule, De Nederduytsche Grammatica ofte Spraec-konst, 5: 'De nutticheyt die de goede Lezer, eyndelik hier door wel zoude mogen bekoomen, is de grondige kennisse aller woorden ende redenen, het welk vervolgens (door Godes zegen) eenen wech ofte opene deure tot alle wetenschappen opent.'

73 Van Niervaert, Oprecht onderwijs van de letter-konst, sig. D7v: 'Leert lezen en schrijven in u jonge jaren:/En wilt aan de Penne gelt noch arbeyd sparen,/Want de ongeleerde moet voor de geleerde nygen.' 


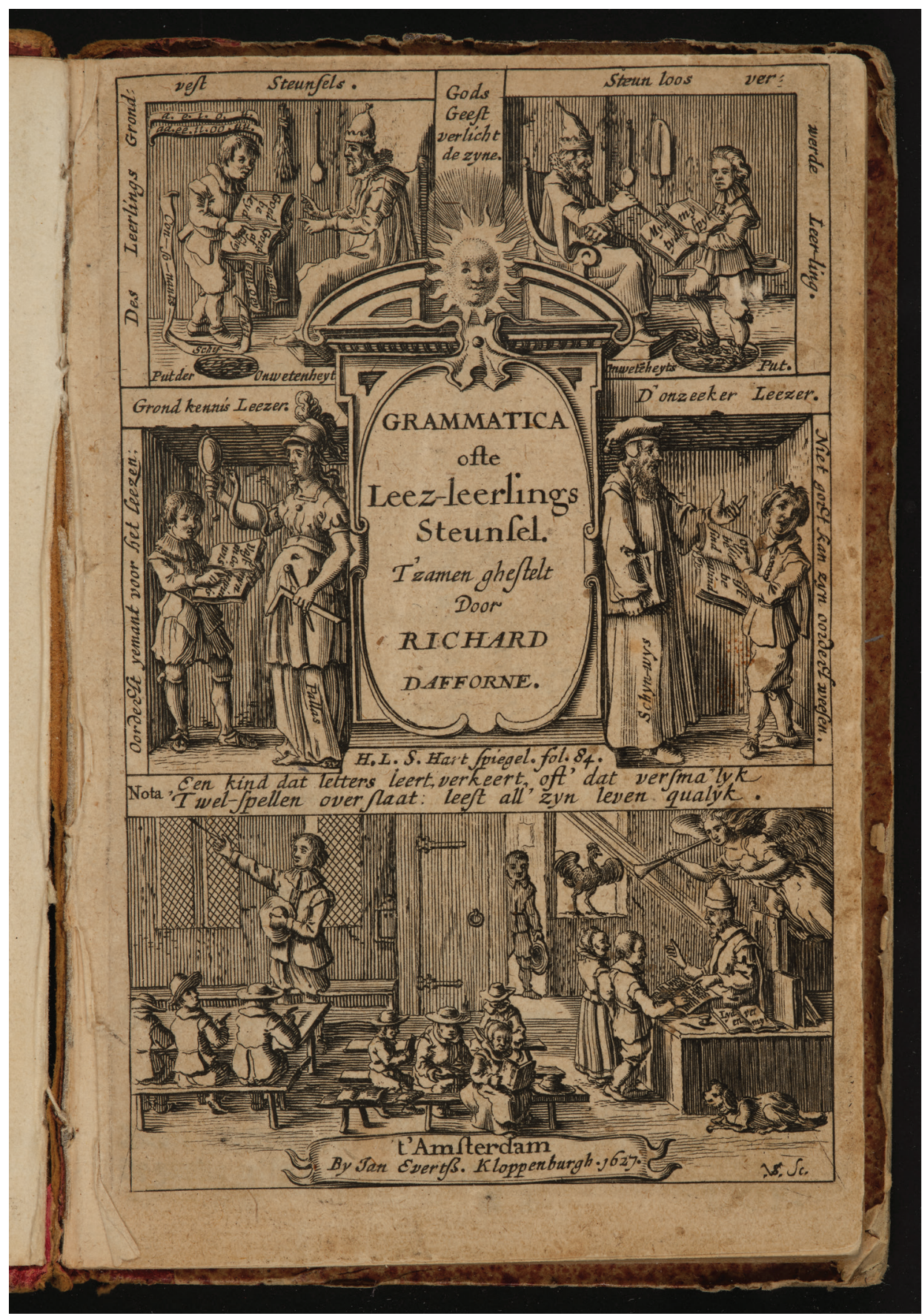

Fig. 5 Richard Dafforne, Grammatica ofte leez-leerlings steunsel naar de Onder-wyzinghe des fondaments der Neder-duytscher orthographie, Amsterdam 1627. Amsterdam, University Library, Special Collections. 
For this reason, too, the corpus of linguistic textbooks can also be considered a trading zone: schoolmasters in particular created an intermediate sphere between the reader's own daily use of the language and the world of (new) knowledge that could be explored once the key to the printed word was mastered. This intermediary role of linguistic textbooks is exemplified by David van Hoogstraten's Aenmerkingen over de geslachten der zelfstandige naemwoorden (Notes on the Genera of Nouns, 1700) which at first sight appears to be one of most normative linguistic textbooks printed in the Dutch Republic: it offers a strict organisation of a restricted selection of nouns in a list, and as such provides a typical example of the trend towards prescription rather than exploration. ${ }^{74}$ It was the most popular eighteenth-century Dutch dictionary and school grammar, as evidenced by the number of reprints and the references to the book by eighteenth-century Dutch authors and schoolmasters. ${ }^{75}$ As we learn from its preface, the book was written in service of 'eagerly learning' Dutch youth:

The craving for our language, even though often ignored by me because of more pressing engagements, has urged me to produce this, in service of the eagerly learning youth who are often misled by teachers unexperienced in this respect; I myself have no problem showing how many hours of study I put in to account for my expertise to those who are knowledgeable about our mother tongue. ${ }^{76}$

Van Hoogstraten wished to transfer his passion for and knowledge of the Dutch language to future generations, before their appetite would be spoiled by inexperienced teachers. The gaining of semantic knowledge was a matter of responding to but also controlling one's cravings: his readers must fully accept the guidance and authority Van Hoogstraten claims to offer, and the trait de liaison he promises to be. As De Bont and Dibbets have argued, his authority was grounded in the work of the exemplary authors Joost van den Vondel and Pieter Cornelisz. Hooft. Van Hoogstraten has simply followed their lead in the attribution of gender to the nouns he lists. ${ }^{77}$

For Van Hoogstraten, knowledge of a lexicon was knowledge of an organized system - hence the presentation of this knowledge as a list. It could be explored by the young 'curious reader' thanks to this strict organization: 'I found the usual way of presenting the most important and most used words as in an index, in alphabetic order, very useful: when in need, the curious reader can see in the blink of an eye how to use any given word. ${ }^{78}$ While exploring the language and learning how to apply it, confusion is to be avoided at all costs. When an issue related to a word's grammatical case arises

74 Van Hoogstraten, Aenmerkingen. The book was subsequently reprinted as Lyst der gebruikelykste zelfstandige naemwoorden.

75 Bakker and Dibbets, Geschiedenis van de Nederlandse taalkunde, 66.

76 Van Hoogstraten, Aenmerkingen, preface, sig. ${ }^{* *} \mathrm{r}$ : 'Maer de zucht tot onze tale, schoon ik die, belet door zwaerder bezigheden, nu minder oeffene, dan voorheen, heeft my hier toe aengezet ten dienst der leerzame Jeugt, die meenigmael al vroeg van hare leermeesteren, onervaren in deze dingen, bedorven, daerna bezwaerlyk den hoek te boven raekt; latende my voorstaen dat ik de uren, hier aen besteedt, lichtelyk zal verantwoorden voor de kenners onzer moedersprake.'

77 De Bont and Dibbets, Voor rede vatbaar, 2.

78 Van Hoogstraten, Aenmerkingen, preface, sig. 4r: 'Ik vond dan geen beter middel, dan de voornaemste en gebruikelyxte woorden, als in een register, op het A B te brengen, op dat de nieusgierige lezer, wanneer hy zich verlegen vondt, met eenen opslag konde zien hoe hy dit of dat woordt moest gebruiken.' 


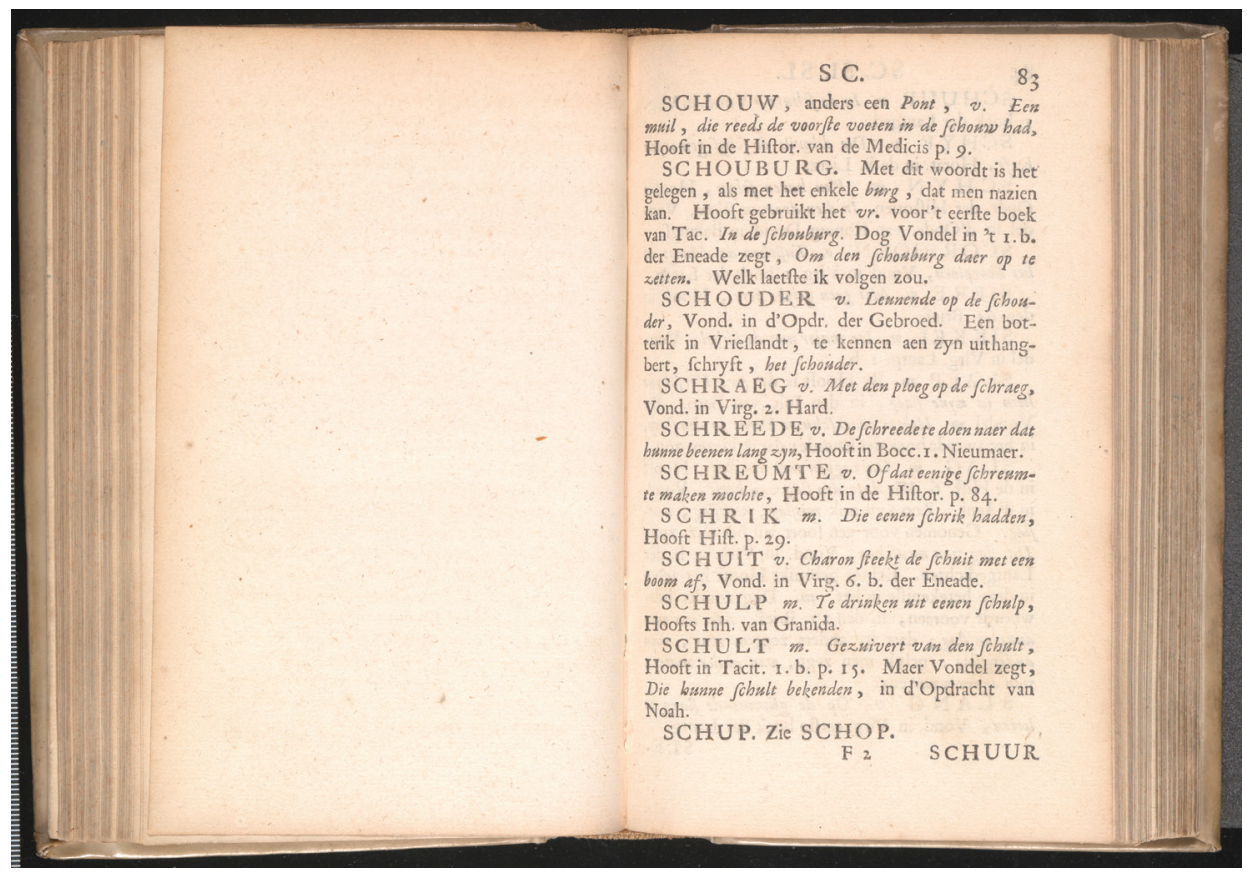

Fig. 6 David van Hoogstraten, Aenmerkingen over de geslachten der zelfstandige naemwoorden, Amsterdam 170o, The Hague, Royal Library, Special Collections.

and cannot be solved, one should relinquish using the particular case or search for an alternative. ${ }^{79}$

The indexes of the sort of semantic knowledge Van Hoogstraten provides are fixed, as is his instruction, but he offers another means of acquiring semantic knowledge that opens up the possibility of explorations by the Dutch youth. Young readers should read literary works by excellent authors and record any word or use of a word that sparks their interest. Van Hoogstraten advises them to have blank sheets bound into their copies of his books, so that, based on their own reading, they can take notes about words he missed: 'Adding words is facilitated if you have blank pages bound into the copy of this book, so you can accumulate and use this list based on your own experience.8o A copy of Van Hoogstraten's book kept in the Royal Library of The Hague (fig. 6) indeed has such blank pages bound in with the printed sheets. The blank pages in this particular copy show no signs of handwriting, but underline the relationship between inquisitiveness, youth, language, and knowledge Van Hoogstraten envisions.

Writing in one's textbook, as was suggested by Van Hoogstraten, had in fact been forbidden as an abuse of paper in the school order of 1602. As Van Niervaert repeated in 1639:

79 Van Hoogstraten, Aenmerkingen, preface, sig. 6v.

80 Van Hoogstraten, Aenmerkingen, sig. ${ }^{* *} 3 \mathrm{v}:$ 'Waer toe goede gelegenheit is, als gy deze bladen laet doorschieten met schoon papier, om uyt eigene ondervindinge deze lyst te vermeerderen'. 
No one shall - on the spur of the moment - draw a doll, horse, cat, or dog; nothing but one's name should be written down. Instead, one should strive for clean sheets without any ink or other filth. ${ }^{81}$

Van Hoogstraten's Aenmerkingen over de geslachten der zelfstandige naemwoorden diverts from that ruling, and reveals the idea that knowledge derives from one's appropriating the system represented by language. Writing down one's ondervindinge (observations), based on one's own reading and an exploration of language used by others, is an inherent part of the acquisition of linguistic knowledge: the implication is that everyone should acquire a vocabulary of one's own, based on individual observations that complement the standard list provided by Van Hoogstraten. Fallardus Kok's Ont-werp der Neder-duitsche letter-konst (Design of the Dutch syntax, 1649), already suggested the value of such an approach, as is obvious from the volume's subtitle: 'Gathered from the nature of the Dutch language, the common use of this language, as well as the use of the Dutch language by exemplary authors. ${ }^{82}$ Kok envisioned that the cutting edge of understanding about the Dutch language and the use of that language by good writers would form the best syntactic training ground for young pupils. His principal advice was the study of examples provided by authors who had mastered the Dutch language, akin to what Van Hoogstraten would propose in 1700. However, Kok overwhelmed his young readers with his own examples, writing for instance that 'I will give yet another example of the use of auxiliary verbs, for those who want to become knowledgeable'. ${ }^{83}$ Van Hoogstraten transfers the responsibility for finding these examples to the young reader.

\section{Conclusion}

Linguistic knowledge was systematically and persistently offered to the youth in the Dutch Republic from the middle of the sixteenth century onwards. Around 1550, the knowledge proffered was restricted to orthography, but by 1650 a more diverse corpus of phonological, syntactical, and semantic knowledge was introduced. As more books on a certain knowledge domain were published (as with textbooks on orthography), they became more normative in nature. An experimental and empirical approach, however, can be found even in the more normative textbooks. Because language is not simply just a set of fixed rules, it cannot be studied without observing variants and irregularities - and these can only be found and processed through empirical observations of one's own production of language and sound. Pupils were encouraged to inspect their own use of the Dutch language in order to best understand linguistic mechanisms and derivations. Since these

81 Van Niervaert, Oprecht onderwijs van de letter-konst, sig. A6v: 'Niemant en sal op zijn School-boeken [...] maken nog schrijven eenige Grillen als Mannekens, Paarden, Katten, Honden [...], ten ware alleenlijk zijnen name: maar sal veel eer alle vlyt aanwenden, om deselve suyver en schoon sonder Inkt, kladden ofte andere vuyligheden te bewaren.'

82 Kok, Ont-werp der Neder-duitsche letter-konst: 'Uit de Natuur der Neder-duitsche Taal, de redelijke ghewoonte en 't ghebruik de ghoede Schrijvers, ten besten van alle Lief-hebbers der zelve [...] t'saam-ghe-stelt.'

83 Kok, Ont-werp der Neder-duitsche letter-konst, 46: 'Op dat men nu weete hoe men de andere Werk-woorden met deze Help-woorden buighen moet, zo zal ik den Leer-ghierighen ten besten hier nóch een Voor-beeldt by-voeghen.' 
textbooks were geared towards sparking an interest in the observation of language, it can be assumed that they exerted a substantial societal impact and thus made possible changes in the knowledge culture of the Dutch Republic.

The tendency to present language as a trading zone was at the heart of this knowledge acquisition. Lambrecht, Van der Schuere, and others created a zone filled with professionals - ministers, schoolmasters, and canons - that received philological training at the universities and schools they attended, and used their knowledge of the book industry to disseminate this knowledge to a wider, young audience. They attempted to materialize this zone in the textual format they chose, be it a list (Van Hoogstraten) or a dialogue (Lambrechts). Also, visual metaphors urged users of these book to look upon language as an object: as a tree loaded with knowledge, waiting to be plucked by the delver ((Montanus); as the pathway to every knowledge domain (Van Niervaert); or as an object without outer limit that could be supplemented with one's own observations (Van Hoogstraten). Since the acquisition of linguistic knowledge was partly based on an individualized and empirically based search, there must have been discussions in classroom settings. These books taught young readers about the intersubjectivity of their own observations, but also showed them a gateway to new knowledge. Didactic techniques urged young readers to contemplate their own role in the acquisition of knowledge and were made aware of the role guides like Lambrecht, Montanus, and Van Hoogstraten played in the augmentation and distribution of knowledge.

Given that many children and young adults were enrolled in the school system of the Dutch Republic at the time, it can be assumed that introducing the Dutch language as an object of empirical and intellectual study affected the knowledge culture in general. The large numbers of books on the subject of language that were printed in the Dutch Republic certainly suggests that linguistic knowledge formed more than a lot of classroom hot air, but had a certain physical presence. Approaching the linguistic textbooks as stimuli for empirical observation and acknowledging the trading zone these textbooks created, perhaps implies a rewriting of the perspective on how sixteenth-century pedagogical views - as in, for instance, Erasmus's De pueris instituendis (On a liberal education for children, 1529) - affected and dominated youth textbooks up to the Enlightenment. As sixteenth-century pedagogical views were based on the assumption that children were sinful at birth, and thus in need of the correction given to them by the church, their parents, their teachers, and the books they were to read, textbooks used in schools were disciplining instruments. They imparted their specific forms of knowledge in a strict and set order. Scholars have often assumed that from the beginning of the eighteenth century onwards, textbooks as well as children's literature changed - from being a disciplining instrument and a pre-processed body of knowledge to a type of literature that actively promoted curiosity and inquisitiveness, in line with the emerging Enlightenment ideology that regarded the child as a tabula rasa. ${ }^{84}$ Parallel to this development, new educational ideals and models were adopted. ${ }^{85}$ The main character of The Family Instructor (1715) for instance, an educational treatise by Daniel Defoe - the author of Robinson Crusoe (1719), initially an

84 See for instance Cunningham, Children and Childhood.

85 Jacobs, The First Knowledge Economy. See for the Dutch context: Put, De cleijne schoolen. 
adult novel that became one of the most successful children's novels ever written - is a young boy who excels in asking his parents every thinkable question. Similar trends have been observed in children's books. ${ }^{86}$ Penny Brown has highlighted how eighteenth-century French children's books used dialogues to intrigue and stimulate the minds of young female readers. Émilie, the protagonist of Louise d'Epinay's Les Conversations d'Émilie, is 'bright and chirpy, self-confident and often funny, endlessly curious and of course eager to learn' ${ }^{87}$ Émilie's curiosity is obvious in her lengthy dialogues with adults, whose praise of her inquisitive behaviour sent a strong message to young readers. Nina Christensen has described how fictive letters in eighteenth-century Danish children's books also sought to spark curiosity, as evident from prefaces whose authors declare that they anticipated their young audience to be naturally curious about the topics they have chosen to address. ${ }^{88}$

Long before these eighteenth-century developments, Dutch sixteenth-century linguistic textbooks intended to spur empirical observation by young readers, by presenting the Dutch language as an object that could be empirically explored and thus obtained. A more detailed analysis of the protagonists involved in the creation of the linguistic trading zone is needed to conclude whether the impact of their potential to profoundly influence early modern knowledge culture justifies the acknowledgement of a linguistic trading zone as an important breeding ground for the welcoming or even encouragement of empirical observations by Dutch youth.

\section{Bibliography}

Bakker, Dirk Miente, and Geert Dibbets, Geschiedenis van de Nederlandse taalkunde (Den Bosch 1977).

Brown, Penny, "'Girls Aloud”. Dialogue as a Pedagogical Tool in Eighteenth-Century French Children's Literature', Lion and the Unicorn 33 (2009) 202-218.

Bont, Ronald de, and Geert Dibbets, Voor rede vatbaar. Tien voorredes uit het grammaticale werk van Van Hoogstraten, Nylöe, Moonen, Sewel, Ten Kate, Huydecoper (1700-1730) (Amsterdam/Münster 1995).

Buringh, Eric, and Jan Luiten van Zanden, 'Charting the "Rise of the West". Manuscript and Printed Books in Europe, a Long-Term Perspective from the Sixth through Eighteenth Centuries', Journal of Economic History 69 (2009) 409-445.

Burke, Peter, Languages and Communities in Early Modern Europe (Cambridge 2004).

Christensen, Nina, 'Lust for Reading and Thirst for Knowledge. Fictive Letters in a Danish Children's Magazine of 1770', Lion and the Unicorn 33 (2009) 189-201.

Cickx-Indestege, E., 'The first edition of the Naembouck by Joos Lambrecht (1546), Quaerendo 1 (1971) 13-15.

Considine, John, Dictionaries in Early Modern Europe. Lexicography and the Making of Heritage (Cambridge 2008).

Cunningham, Hugh, Children and Childhood in Western Society since 1500 (London 2014).

Dafforne, Richard, Grammatica ofte leez-leerlings steunsel naar de Onder-wyzinghe des fondaments der Neder-duytscher orthographie (Amsterdam: Jan Evertsz. Cloppenburg, 1627).

De Keyser, Paul, 'Bronnen van Joos Lambrechts Nederlandsche Spellijnghe', Revue belge de philologie et d'histoire 7 (1928) 1345-1362.

86 Jochum, 'Defoe's Children', 157-159.

87 Brown, “'Girls Aloud”', 212. See also O'Malley, The Making of the Modern Child.

88 Christensen, 'Lust for Reading and Thirst for Knowledge', 191. 
De Neve, Otto, 'Aantekeningen over 16de-eeuwse lexicografie,' Tijdschrift voor Nederlandse Taal- en Letterkunde 79 (1963) 200-210.

Dictionarium tetraglotton (Antwerp: Christoffel Plantin, 1562).

Dorren, Gabriele, Eenheid en verscheidenheid. De burgers van Haarlem in de Gouden Eeuw (Amsterdam 2001).

Estienne, Robert, Traicté de la Grammaire Francoise. Colette Demaizière (ed.) (Paris 2003), https://dhfles. revues.org/1274 (Accessed on 4 November 2021).

Frijhoff, Willem, Marie-Christine Kok Escalle, and Karène Sanchez-Summerer, 'Languages and Culture in History', in Willem Frijhoff, Marie-Christine Kok Escalle, and Karène Sanchez-Summerer (eds.), Multilingualism, Nationhood, and Cultural Identity. Northern Europe, 16th-19th Centuries (Amsterdam 2016) 7-13.

Frijhoff, Willem, and Marijke Spies, Dutch Culture in a European Perspective. 1650. Hard-Won Unity (Assen 2004).

Galison, Peter, Image and Logic. A Material Culture of Microphysics (Chicago 1997).

Gelderblom, Arie-Jan, “"Nieuwe stof in Neerlandsch”. Een karakteristiek van Coornherts proza', in Henk Bonger, J.R.H. Hoogervorst, Nicolette Mout, Ivo Schöffer, and Juliaan Woltjer (eds.), Dirck Volckertszoon Coornhert. Dwars maar recht (Zutphen 1989) 98-114, 177.

Haar, Alisa van de, "Van "nimf" tot "schoolvrouw". De Franse school en haar onderwijzeressen in de zestiende- en zeventiende-eeuwse Nederlanden', Historica 38 (2015) 11-16.

Haar, Alisa van de, The Golden Mean of Languages. Forging Dutch and French in the Early Modern Low Countries (1540-1620) (Leiden 2019).

Hal, Toon Van, 'A Man of Eight Hearts. Hadrianus Junius And Sixteenth-Century Plurilinguism', in Dirk van Miert (ed.), The Kaleidoscopic Scholarship of Hadrianus Junius (1511-1575). Northern Humanism at the Dawn of the Dutch Golden Age (Leiden 2011) 188-213.

Harun, Karim, 'Latin Influence in Early Malay Grammars', Jurnal Melayu 4 (2009) 1-10.

Heuiter, Pontus de, Nederduitse orthographie. Geert Dibbets (ed.) (Groningen 1972).

Hofman, Johan, Nederlandtsche Woorden-Schat, dat is, Verduytschinge van Uytheemsche woorden, die somtijdts onder het Nederlandtsch gevonden worden (Haarlem: Thomas Fonteyn, 1650).

Hoogstraten, David van, Aenmerkingen over de geslachten der zelfstandige naemwoorden (Amsterdam 2nd ed.: François Halma, 1713).

Heule, Christiaan van, De Nederduytsche Grammatica ofte Spraec-konst. Willem Johannes Hubertus Caron (ed.) (Groningen 1953).

Hulsker, Johannis, Petrus Montanus, De spreeckonst nader besproken. Een bijdrage tot de geschiedenis van de Nederlandse taalkunde (Oisterwijk 1991).

Jacobs, Margaret, The First Knowledge Economy. Human Capital and the European Economy, 1750-1850 (Cambridge 2014).

Jochum, Klaus Peter, 'Defoe's Children', in Anja Müller (ed.), Fashioning Childhood in the Eighteenth Century. Age and Identity (Ashgate 2006) 157-167.

Kok, Allardus, Ont-werp der Neder-duitsche letter-konst. Geert Dibbets (ed.) (Assen 1981).

Langereis, Sandra, De woordenaar. Christoffel Plantijn. 's Wereld's grootste drukker en uitgever (1520-1589) (Amsterdam 2014).

Lambrecht, Joos, Naembouck van allen naturelicken ende ongheschuumden vlaemschen woirden by a $b c$ overghezett in walscher tale (Ghent: Joos Lanbrecht, 1546).

Lambrecht, Joos, Het naembouck van 1562. Tweede druk van het Nederlands-Frans woordenboek. René Verdeyen (ed.) (Paris 1945).

Lambrecht, Joos, Nederlandsche spellijnghe, uutghesteld by vraghe ende antwoorde. Tot onderwijs der jonghers voor haar earste beghin. Ferdinand Heremans and Frans Vanderhaeghen (eds.) (Ghent 1882).

Long, Pamela, 'Trading Zones in Early Modern Europe', Isis 106 (2015/4) 840-847.

O'Malley, Andrew, The Making of the Modern Child. Children's Literature and Childhood in the Late Eighteenth Century (New York 2003). 
Montanus, Petrus, Bericht van een niewe konst, genaemt de spreeckonst (Delft: Jan Pietersz. Waalpot, 1635). Niervaert, Cornelis Dirckz. van, Oprecht onderwijs van de letter-konst (Purmerend: Pieter Jordaan, 1743).

Put, Eddy, De cleijne schoolen. Het volksonderwijs in het hertogdom Brabant tussen Katholieke Reformatie en Verlichting (eind 16de eeuw-1795) (Leuven 1990).

Rener, Frederick M., Interpretatio. Language and Translation from Cicero to Tytler (Leiden 1989).

Rutten, Gijsbert, and Marijke J. van der Wal, Letters as Loot. A Sociolinguistic Approach to Seventeenth- and Eighteenth-Century Dutch (Amsterdam 2014).

Ruijsendaal, Els, Letterkonst. Het klassieke grammaticamodel en de oudste Nederlandse grammatica's (Amsterdam 1991).

Schuere, Jacob van der, Nederduydsche spellinge. F.L. Zwaan (ed.) (Groningen 1957).

Smyters, Anthoni, Epitheta, dat zijn bynamen oft toenamen (Rotterdam: Jan van Waesberghe, 1620).

Spiegel, Hendrik Laurensz., Twe-spraack vande Nederduitsche letterkunst (Leiden: Christoffel Plantijn, 1584).

Sterkenburg, Piet van, Van woordenlijst tot woordenboek. Inleiding tot de geschiedenis van woordenboeken van het Nederlands (Leiden 1984).

Sijs, Nicoline van der, 'Joos Lambrecht. Vernieuwer in spelling en typografie', in Lieke van Deissen and Ton van Strien (eds.), Panpoëticon Batavum/Schrijverskabinet, http://www.schrijverskabinet.nl/artikel/ joos-lambrecht/ (Accessed on 4 November 2021).

Sijs, Nicoline van der (ed.), Het versierde woord. De Epitheta of woordcombinaties van Anthoni Smyters uit 1620 (Amsterdam 1999).

Van Hal, Toon, 'Moedertalen en taalmoeders'. Het vroegmoderne taalvergelijkende onderzoek in de Lage Landen (Leuven 2010).

Vries, Jan W. de, Roland Willemyns, and Peter Burger, Het verhaal van een taal. Negen eeuwen Nederlands (Amsterdam 1993).

Walker Read, Allen, 'The History of Dr. Johnson's Definition of “Oats"', Agricultural History 8 (1934) 81-94.

Waterschoot, Werner, 'Antwerp. Books, Publishing and Cultural Production before 1585', in Patrick O'Brien (ed.), Urban Achievement in Early Modern Europe. Golden Ages in Antwerp, Amsterdam and London (Cambridge 2001).

Waterschoot, Werner, 'De Gentse drukkers Joos Lambrecht en Jan Cauweel', De zeventiende eeuw 8 (1992) 27-31.

Winschooten, Wigardus à, Letterkonst, sijnde het eerste deel van de Neederlandse spraakkonst (Leiden: s.n., 1683). 